\title{
Questions and answers in Evidence-based Dentistry volume 10
}

\section{Derek Richards \\ Editor, Evidence-based Dentistry}

As in previous years, we highlight here the guidelines, questions and answers

addressed by summaries in Evidence-based Dentistry. ${ }^{1-7}$

Evidence levels ${ }^{8}$ are only given for those papers that achieved level $3 \mathrm{~A}$ and above.

Evidence-Based Dentistry (2009) 10, 120-123. doi:10.1038/sj.ebd.6400691

\begin{tabular}{|c|c|c|c|}
\hline Topic area & Question & Answer & Page \\
\hline Caries & $\begin{array}{l}\text { When attempting to prevent } \\
\text { dental caries in elderly people } \\
\text { who live in residential care } \\
\text { homes, what is the effectiveness } \\
\text { and relative cost benefit of } \\
\text { high-concentration fluoride } \\
\text { toothpaste compared with } \\
\text { fluoride varnish application? }\end{array}$ & $\begin{array}{l}\text { For elderly populations in residential care, in areas with low levels of fluoride } \\
\text { in drinking water, who are assessed as being at increased risk of dental caries: } \\
\text { toothbrushing carried out twice daily with a } 2800 \text { ppm fluoride paste, following } \\
\text { the manufacturer's instructions regarding quantity, is likely to give improved caries } \\
\text { control over standard toothpaste while avoiding any risk of toxicity. On completion } \\
\text { of brushing, the mouth should not be rinsed, but as much paste as possible should be } \\
\text { expectorated. In addition, although costly, consideration could be given to applying } \\
5 \% \text { sodium fluoride varnish to the same population three to four times per year. }\end{array}$ & $83-87$ \\
\hline
\end{tabular}

\begin{tabular}{|c|c|c|c|c|}
\hline \multicolumn{5}{|l|}{ Summaries } \\
\hline Topic & Question & Answer & $\begin{array}{l}\text { Evidence } \\
\text { level }\end{array}$ & Page \\
\hline \multirow[t]{6}{*}{ Caries } & $\begin{array}{l}\text { Are polyol-containing chewing gums } \\
\text { effective in reducing dental decay? }\end{array}$ & $\begin{array}{l}\text { There is consistent evidence to support the use of xylitol- and } \\
\text { sorbitol-containing chewing gum to prevent dental caries. }\end{array}$ & $1 a$ & $10-11$ \\
\hline & $\begin{array}{l}\text { Are fluoride interventions effective } \\
\text { for the prevention of root caries } \\
\text { in adults? }\end{array}$ & $\begin{array}{l}\text { The available studies suggest that increasing the regular daily } \\
\text { delivery of fluoride has a beneficial effect, reducing root caries. }\end{array}$ & $1 b$ & 12 \\
\hline & $\begin{array}{l}\text { Is SDF more effective than fluoride } \\
\text { varnish in preventing caries? }\end{array}$ & $\begin{array}{l}\text { Results suggest that SDF is more effective than fluoride varnish, and } \\
\text { may be a valuable caries-preventive intervention. }\end{array}$ & $1 b$ & 68 \\
\hline & $\begin{array}{l}\text { Can an oral health promotion } \\
\text { programme starting during } \\
\text { pregnancy prevent ECC in } \\
\text { young children? }\end{array}$ & $\begin{array}{l}\text { A programme based on repeated rounds of anticipatory guidance } \\
\text { initiated during the mother's pregnancy was successful in reducing } \\
\text { the incidence of ECC. }\end{array}$ & $1 b$ & $\begin{array}{l}100- \\
101\end{array}$ \\
\hline & $\begin{array}{l}\text { What are the risk determinants } \\
\text { of ECC in children? }\end{array}$ & $\begin{array}{l}\text { This case-control study showed that children of different } \\
\text { socioeconomic backgrounds who have ECC share the common } \\
\text { risk indicators of visible plaque, consumption of sugary snacks and } \\
\text { presence of Streptococcus mutans. Additional risk indicators in } \\
\text { children from childcare facilities were enamel hypoplasia, difficulty } \\
\text { in cleaning the child's teeth, sweetened drinks and maternal } \\
\text { anxiety, whereas ethnicity and mothers' access to pension or } \\
\text { healthcare cards were specific to the public hospital cases. }\end{array}$ & $\mathrm{n} / \mathrm{a}$ & $37-38$ \\
\hline & $\begin{array}{l}\text { Is a daily } \mathrm{CHX} \text { mouthrinse effective } \\
\text { at reducing caries in a community- } \\
\text { dwelling elderly population? }\end{array}$ & $\begin{array}{l}\text { Findings suggest that regular rinsing with } \mathrm{CHX} \text { does not have a } \\
\text { substantial effect on the preservation of sound tooth structure in } \\
\text { older adults. }\end{array}$ & $1 b$ & $13-14$ \\
\hline Delivery of care & $\begin{array}{l}\text { What is the effectiveness and } \\
\text { cost-effectiveness of sedation } \\
\text { vs general anaesthesia for the } \\
\text { provision of dental treatment for } \\
\text { under } 18 \text {-year olds? }\end{array}$ & $\begin{array}{l}\mathrm{RCT} \text { are required that compare the use of dental general } \\
\text { anaesthesia with sedation, to quantify differences such as } \\
\text { morbidity and cost. }\end{array}$ & $\mathrm{n} / \mathrm{a}$ & 69 \\
\hline \multirow[t]{2}{*}{$\begin{array}{l}\text { Dental public } \\
\text { health }\end{array}$} & $\begin{array}{l}\text { Does improved oral hygiene } \\
\text { lead to reductions in cases of } \\
\text { pneumonia and respiratory tract } \\
\text { infections in elderly people in } \\
\text { hospitals and nursing homes? }\end{array}$ & $\begin{array}{l}\text { RCT provide evidence that mechanical oral hygiene decreases } \\
\text { mortality risk from pneumonia and seems to have a clinically } \\
\text { relevant preventive effect on nonfatal pneumonia in independent } \\
\text { elderly individuals. }\end{array}$ & $1 \mathrm{a}$ & 46 \\
\hline & $\begin{array}{l}\text { Does the use of infant formula } \\
\text { compared with the use of breast } \\
\text { or cow's milk increase the risk of } \\
\text { fluorosis? }\end{array}$ & $\begin{array}{l}\text { Infant formula consumption may be associated with an increased risk } \\
\text { of developing at least some detectable level of enamel fluorosis, but } \\
\text { this depends on the level of fluoride in the water supply. The evidence } \\
\text { that the fluoride in the infant formula caused enamel fluorosis was } \\
\text { weak, as other mechanisms could explain the observed association. }\end{array}$ & $\mathrm{n} / \mathrm{a}$ & 73 \\
\hline
\end{tabular}


TOOLBOX

\begin{tabular}{|c|c|c|c|c|}
\hline \multirow[t]{2}{*}{ Endodontics } & $\begin{array}{l}\text { When individuals undergo root } \\
\text { canal treatment, does a single- } \\
\text { visit approach result in a higher } \\
\text { frequency of post-treatment } \\
\text { problems than a multiple-visit one? }\end{array}$ & $\begin{array}{l}\text { Compelling evidence is lacking to indicate any significantly } \\
\text { different prevalence of postoperative pain or flare-up following } \\
\text { either single- or multiple-visit root canal treatment. }\end{array}$ & $2 b$ & 16 \\
\hline & $\begin{array}{l}\text { For orthograde root canal } \\
\text { treatment of permanent } \\
\text { teeth, is hand instrumentation } \\
\text { more effective than ultrasonic } \\
\text { instrumentation when used alone } \\
\text { or as an adjunctive procedure? }\end{array}$ & $\begin{array}{l}\text { This review illustrates the current lack of published or ongoing } \\
\text { RCT, and the lack of availability of high-level evidence dealing } \\
\text { with clinically relevant outcomes, for the effectiveness of } \\
\text { ultrasonic instrumentation used alone or as an adjunct to hand } \\
\text { instrumentation for orthograde root canal treatment. }\end{array}$ & $\mathrm{n} / \mathrm{a}$ & 76 \\
\hline \multirow[t]{2}{*}{ Oral cancer } & $\begin{array}{l}\text { Is low socioeconomic status } \\
\text { associated with increased oral } \\
\text { cancer risk? }\end{array}$ & $\begin{array}{l}\text { Oral cancer risk associated with low socioeconomic status is } \\
\text { significant and related to lifestyle risk factors. }\end{array}$ & $3 a$ & $4-5$ \\
\hline & $\begin{array}{l}\text { What are the lifestyle, } \\
\text { occupational and genetic risk } \\
\text { factors for head and neck and } \\
\text { oesophageal cancers? }\end{array}$ & $\begin{array}{l}\text { These results indicate that periodontal disease (as indicated by poor } \\
\text { condition of the mouth and missing teeth) and daily mouthwash } \\
\text { use may be independent causes of cancers of the head, neck and } \\
\text { oesophagus. }\end{array}$ & $3 a$ & $6-7$ \\
\hline \multirow[t]{3}{*}{ Oral medicine } & $\begin{array}{l}\text { What interventions are effective } \\
\text { for the prevention or treatment, or } \\
\text { both, of HSV in patients receiving } \\
\text { treatment for cancer? }\end{array}$ & $\begin{array}{l}\text { There is evidence that aciclovir is effective at preventing and } \\
\text { treating HSV infections. There is no evidence that valaciclovir is } \\
\text { more efficacious than aciclovir, or that a high dose of valaciclovir is } \\
\text { better than a low dose of valaciclovir. There is evidence that, as a } \\
\text { prophylaxis, placebo is more efficacious than prostaglandin E. In all } \\
\text { included trials the risk of bias was unclear. }\end{array}$ & $1 a$ & $\begin{array}{l}116- \\
117\end{array}$ \\
\hline & $\begin{array}{l}\text { Are sublingual vitamin B12 tablets } \\
\text { effective in reducing the frequency } \\
\text { of recurrent aphthous stomatitis } \\
\text { episodes? }\end{array}$ & $\begin{array}{l}\text { Vitamin B12 treatment, which is simple, inexpensive and low-risk, } \\
\text { seems to be effective for patients suffering from recurrent aphthous } \\
\text { stomatitis, regardless of the serum vitamin B12 level. }\end{array}$ & $1 b$ & $\begin{array}{l}114- \\
115\end{array}$ \\
\hline & $\begin{array}{l}\text { What treatments are effective in } \\
\text { managing restricted jaw opening } \\
\text { or movement in people who have } \\
\text { oral submucous fibrosis? }\end{array}$ & $\begin{array}{l}\text { The lack of reliable evidence for the effectiveness of any specific } \\
\text { interventions for the management of oral submucous fibrosis is } \\
\text { illustrated by the paucity, and poor methodological quality, of trials } \\
\text { retrieved for this review. }\end{array}$ & $2 b$ & $8-9$ \\
\hline \multirow[t]{4}{*}{ Oral surgery } & $\begin{array}{l}\text { In people taking warfarin and } \\
\text { who are undergoing elective } \\
\text { dental procedures, what is the } \\
\text { risk of bleeding for patients } \\
\text { who continue warfarin therapy } \\
\text { compared with those whose dose } \\
\text { is reduced or interrupted? }\end{array}$ & $\begin{array}{l}\text { Continuing the regular dose of warfarin therapy does not seem to } \\
\text { confer an increased risk of bleeding compared with discontinuing } \\
\text { or modifying the warfarin dose in people undergoing minor } \\
\text { dental procedures. }\end{array}$ & $1 \mathrm{a}$ & 52 \\
\hline & $\begin{array}{l}\text { Is } \mathrm{CHX} \text { gel more effective than } \\
\mathrm{CHX} \text { rinse in reducing alveolar } \\
\text { osteitis in mandibular third molar } \\
\text { surgery? }\end{array}$ & $\begin{array}{l}\text { It was concluded that the topical application of bioadhesive } \mathrm{CHX} \\
\text { gel to the surgical wound during the postoperative week may } \\
\text { decrease the incidence of alveolar osteitis after extraction of the } \\
\text { mandibular third molars. In view of the unexplained results of the } \\
\text { study, the conclusions should be viewed with discretion. }\end{array}$ & $1 b$ & $54-55$ \\
\hline & $\begin{array}{l}\text { Is botulinum toxin safe to be } \\
\text { used prophylactically in people } \\
\text { undergoing dental implant therapy? }\end{array}$ & $\begin{array}{l}\text { At present there are no studies that demonstrate any beneficial or } \\
\text { adverse effects of botulinum toxin use in dental implantology. }\end{array}$ & $2 b$ & 53 \\
\hline & $\begin{array}{l}\text { How much relapse occurs after } \\
\text { people undergo bilateral sagittal } \\
\text { split osteotomy with rigid internal } \\
\text { fixation? }\end{array}$ & $\begin{array}{l}\text { The evidence of variation in relapse rates between rigid internal } \\
\text { fixation methods appear relatively equivocal at the present time. This } \\
\text { review is useful in establishing the current position and highlighting } \\
\text { the need for further high quality, prospective RCT in this area. }\end{array}$ & $2 b$ & $81-82$ \\
\hline \multirow[t]{4}{*}{ Orthodontics } & $\begin{array}{l}\text { In people who are undergoing } \\
\text { orthodontic treatment, are oral } \\
\text { health promotion interventions } \\
\text { effective in improving oral hygiene } \\
\text { and gingival health? }\end{array}$ & $\begin{array}{l}\text { An oral health promotion programme for people undergoing fixed } \\
\text { appliance orthodontic treatment produces a short-term reduction } \\
\text { (up to } 5 \text { months) in plaque and improvement in gingival health. } \\
\text { No particular oral health promotion method produced a greater } \\
\text { short-term benefit to periodontal health during fixed appliance } \\
\text { orthodontic treatment. Further studies using appropriate methods } \\
\text { and in particular longer follow up periods are required. }\end{array}$ & $1 \mathrm{a}$ & $\begin{array}{l}111- \\
112\end{array}$ \\
\hline & $\begin{array}{l}\text { In the first } 6 \text { months after active } \\
\text { orthodontic treatment are } \\
\text { vacuum-formed retainers more } \\
\text { effective than Hawley retainers? }\end{array}$ & $\begin{array}{l}\text { In the } 6 \text { months following debond, vacuum-formed retainers are } \\
\text { more effective than Hawley retainers in maintaining labial segment } \\
\text { alignment. }\end{array}$ & $1 b$ & 47 \\
\hline & $\begin{array}{l}\text { What factors effect the use of } \\
\text { mini-implants for direct or indirect } \\
\text { orthodontic anchorage? }\end{array}$ & $\begin{array}{l}\text { Although temporary anchorage device use in orthodontic } \\
\text { treatment has increased, there are still important clinical and } \\
\text { biological questions to be answered regarding the use of mini- } \\
\text { implants for orthodontic anchorage. }\end{array}$ & $2 a$ & 113 \\
\hline & $\begin{array}{l}\text { What are the effects of the lip } \\
\text { bumper on mandibular arch } \\
\text { dimensions in adolescents? }\end{array}$ & $\begin{array}{l}\text { The results showed increases in arch dimensions, including a greater } \\
\text { arch length. This was attributed to incisor proclination, distalisation, } \\
\text { and distal tipping of the molars. There were also increases in arch width } \\
\text { and intercanine and deciduous intermolar or premolar distances. The } \\
\text { long-term stability of the effects of the lip bumper need to be elucidated. }\end{array}$ & $2 b$ & $48-49$ \\
\hline
\end{tabular}




\begin{tabular}{|c|c|c|c|c|}
\hline & $\begin{array}{l}\text { Can an individual's medication } \\
\text { affect the rate of orthodontic } \\
\text { tooth movement? }\end{array}$ & $\begin{array}{l}\text { The authors identified a need for more well-designed studies } \\
\text { on the effects of various types of medication on orthodontic } \\
\text { tooth movement. }\end{array}$ & $\mathrm{n} / \mathrm{a}$ & $50-51$ \\
\hline & $\begin{array}{l}\text { Does extraction of maxillary } \\
\text { primary canine teeth have a } \\
\text { positive effect on the eruption } \\
\text { of palatally displaced } \\
\text { permanent canines? }\end{array}$ & $\begin{array}{l}\text { There is currently no strong evidence to justify the prophylactic } \\
\text { extraction of deciduous canines in apparently palatally displaced } \\
\text { canines. }\end{array}$ & $\mathrm{n} / \mathrm{a}$ & 102 \\
\hline \multirow[t]{4}{*}{$\begin{array}{l}\text { Paediatric } \\
\text { dentistry }\end{array}$} & $\begin{array}{l}\text { How long should we wait } \\
\text { for a pulp extirpation after } \\
\text { a replantation of an avulsed } \\
\text { permanent tooth? }\end{array}$ & $\begin{array}{l}\text { There is clinical evidence for an association between pulp } \\
\text { extirpation performed after } 14 \text { days following replantation and } \\
\text { the development of inflammatory resorption. This investigation } \\
\text { supports the current clinical guidelines for pulp extirpation within } \\
10-14 \text { days of replantation. }\end{array}$ & $2 b$ & 72 \\
\hline & $\begin{array}{l}\text { What are the most likely effects } \\
\text { of traumatic intrusion of primary } \\
\text { teeth on the permanent successor } \\
\text { teeth? }\end{array}$ & $\begin{array}{l}\text { The majority of intruded primary incisors where immediate } \\
\text { extraction is not indicated will re-erupt if simply observed. Just over } \\
\text { half of permanent successional incisors are likely to have one or } \\
\text { more developmental defects. }\end{array}$ & $2 b$ & $70-71$ \\
\hline & $\begin{array}{l}\text { Do systemic antibiotics prescribed } \\
\text { at the time of replantation of an } \\
\text { avulsed permanent tooth improve } \\
\text { the chances of periodontal healing? }\end{array}$ & $\begin{array}{l}\text { There was inconclusive evidence for an association between } \\
\text { systemic antibiotic therapy and an increased likelihood of } \\
\text { acceptable periodontal healing. }\end{array}$ & $2 b$ & 103 \\
\hline & $\begin{array}{l}\text { For how long should re-implanted } \\
\text { avulsed teeth be splinted? }\end{array}$ & $\begin{array}{l}\text { The evidence appears inconclusive for any association between } \\
\text { short-term splinting and increased likelihood of functional } \\
\text { periodontal healing, acceptable healing, or decreased development } \\
\text { of replacement resorption. }\end{array}$ & $2 b$ & 104 \\
\hline \multirow[t]{10}{*}{$\begin{array}{l}\text { Periodontal } \\
\text { disease }\end{array}$} & $\begin{array}{l}\text { In the treatment of chronic } \\
\text { periodontitis, is full-mouth } \\
\text { debridement and/ or disinfection } \\
\text { more effective than quadrant } \\
\text { scaling and root planing? }\end{array}$ & $\begin{array}{l}\text { The review suggests that mechanical or nonsurgical periodontal } \\
\text { treatment is effective, but showed no difference in the periodontal } \\
\text { clinical outcome measures between the full-mouth debridement } \\
\text { and quadrant approaches. }\end{array}$ & $1 \mathrm{a}$ & 17 \\
\hline & $\begin{array}{l}\text { Does periodontal treatment have } \\
\text { an effect on glycaemic control in } \\
\text { diabetic patients? }\end{array}$ & $\begin{array}{l}\text { This meta-analysis suggests that periodontal treatment could } \\
\text { improve glycaemic control. Nevertheless, these results should } \\
\text { be viewed with caution because of a lack of robustness and } \\
\text { deficiencies in the design of some of the studies included. }\end{array}$ & $1 a$ & $20-21$ \\
\hline & $\begin{array}{l}\text { Does oral irrigation have beneficial } \\
\text { effects in reducing dental plaque } \\
\text { and improving gingival health } \\
\text { over regular oral hygiene or } \\
\text { toothbrushing only? }\end{array}$ & $\begin{array}{l}\text { This systematic review suggests that oral irrigation as an adjunct to } \\
\text { toothbrushing does not have a beneficial effect in reducing dental } \\
\text { plaque, but it may improve gingival health. }\end{array}$ & $1 \mathrm{a}$ & $40-41$ \\
\hline & $\begin{array}{l}\text { Is using woodsticks as an adjunct } \\
\text { to toothbrushing more effective at } \\
\text { reducing periodontal inflammation } \\
\text { than toothbrushing alone? }\end{array}$ & $\begin{array}{l}\text { With the limited data within this review, it is difficult to draw any } \\
\text { meaningful conclusions on the efficacy of woodsticks. }\end{array}$ & $1 a$ & 43 \\
\hline & $\begin{array}{l}\text { Is the use of a of cetylpyridinium } \\
\text { chloride-containing mouthrinses } \\
\text { as an adjunct to toothbrushing } \\
\text { more effective than toothbrushing } \\
\text { alone in preventing plaque } \\
\text { accumulation and gingivitis? }\end{array}$ & $\begin{array}{l}\text { The quality of the available evidence means that the use of } \\
\text { cetylpyridinium chloride mouthrinses as an adjunct to mechanical } \\
\text { plaque control should be considered with caution. }\end{array}$ & $1 a$ & 44 \\
\hline & $\begin{array}{l}\text { Does smoking affect the prognosis } \\
\text { of dental implants? }\end{array}$ & $\begin{array}{l}\text { The risk of implant failures and biological complications with and } \\
\text { without accompanying augmentation procedures was found to be } \\
\text { significantly increased in smokers compared with nonsmokers. }\end{array}$ & $1 b$ & $79-80$ \\
\hline & $\begin{array}{l}\text { Is periodontal disease an } \\
\text { independent novel risk factor for } \\
\text { incident CHD? }\end{array}$ & $\begin{array}{l}\text { Periodontal disease is a risk factor or marker for CHD that } \\
\text { is independent of traditional CHD risk factors, including } \\
\text { socioeconomic status. Further research is warranted in this } \\
\text { important area of public health. }\end{array}$ & $2 a$ & 22 \\
\hline & $\begin{array}{l}\text { Is use of interdental brushes as an } \\
\text { adjunct to toothbrushing more } \\
\text { effective than toothbrushing } \\
\text { alone? }\end{array}$ & $\begin{array}{l}\text { The evidence suggests that interdental brush use as an adjunct } \\
\text { to toothbrushing removes more dental plaque than brushing } \\
\text { alone, being even more effective than dental floss or woodsticks in } \\
\text { removing dental plaque. The evidence available for the effect on } \\
\text { gingival inflammation is less conclusive. The reduction of pocket } \\
\text { depth after the use of the interdental brush is more pronounced } \\
\text { than with floss. }\end{array}$ & $2 a$ & 74 \\
\hline & $\begin{array}{l}\text { What is the association between } \\
\text { long-term smoking and } \\
\text { periodontal disease? }\end{array}$ & $\begin{array}{l}\text { Current and long-term smoking in young adults is detrimental to } \\
\text { periodontal health, but smoking cessation may be associated with a } \\
\text { relatively rapid improvement in the periodontium. }\end{array}$ & $2 b$ & 18-19 \\
\hline & $\begin{array}{l}\text { Is psychological stress a risk factor } \\
\text { for periodontal disease? }\end{array}$ & $\begin{array}{l}\text { Within the limitations of this systematic review, the majority } \\
\text { of studies showed a positive relationship between stress or } \\
\text { psychological factors and periodontal disease. }\end{array}$ & $3 a$ & 42 \\
\hline
\end{tabular}


TOOLBOX

\begin{tabular}{|c|c|c|c|c|}
\hline & $\begin{array}{l}\text { Do manual or electronic probes } \\
\text { produce the most reproducible } \\
\text { measurements of clinical } \\
\text { attachment level in periodontitis } \\
\text { patients? }\end{array}$ & $\begin{array}{l}\text { Manual and electronic probes were of similar reliability when } \\
\text { used to measure clinical attachment level in individuals who had } \\
\text { untreated periodontitis and when used by a calibrated examiner, } \\
\text { but this finding is not supported by strong evidence. }\end{array}$ & $\mathrm{n} / \mathrm{a}$ & 39 \\
\hline & $\begin{array}{l}\text { How effective is the Vector (Dürr } \\
\text { Dental, Bietigheim-Bissingen, } \\
\text { Germany) ultrasonic scaler on } \\
\text { human teeth in vitro and in vivo } \\
\text { compared with conventional } \\
\text { ultrasonic instruments and/ or } \\
\text { hand instrumentation? }\end{array}$ & $\begin{array}{l}\text { The vector ultrasonic scaler may be used as a gentle root } \\
\text { debridement device for supportive periodontal therapy, as } \\
\text { an alternative to other conventional ultrasonic systems. The } \\
\text { operator should consider, however, the extra time needed for } \\
\text { instrumentation. }\end{array}$ & $\mathrm{n} / \mathrm{a}$ & 45 \\
\hline & $\begin{array}{l}\text { Does the treatment of periodontal } \\
\text { disease during pregnancy reduce } \\
\text { the incidence of preterm birth? }\end{array}$ & $\begin{array}{l}\text { Periodontal therapy did not reduce the incidence of } \\
\text { preterm delivery. }\end{array}$ & $1 b$ & 105 \\
\hline \multirow[t]{6}{*}{$\begin{array}{l}\text { Restorative } \\
\text { dentistry }\end{array}$} & $\begin{array}{l}\text { When people require dental } \\
\text { implants in the aesthetic } \\
\text { zone, is there any difference } \\
\text { in the outcome measures } \\
\text { between immediate, early and } \\
\text { conventionally placed implants? }\end{array}$ & $\begin{array}{l}\text { The selected studies provide promising short-term results for } \\
\text { immediate, early and conventional single-implants in the aesthetic } \\
\text { zone. Important parameters, such as aesthetic outcome, peri- } \\
\text { implant structures and patient satisfaction, however, still need } \\
\text { further evaluation. The outcome measures could not be fully } \\
\text { evaluated when comparing immediate, early and conventional } \\
\text { implants because of the lack of RCT. }\end{array}$ & $1 a$ & $77-78$ \\
\hline & $\begin{array}{l}\text { What is the safest and most } \\
\text { effective method of cleaning } \\
\text { removable dentures? }\end{array}$ & $\begin{array}{l}\text { There is a lack of evidence about the comparative effectiveness of } \\
\text { the different denture cleaning methods considered in this review. }\end{array}$ & $1 a$ & 109 \\
\hline & $\begin{array}{l}\text { Are nanohybrid composite } \\
\text { restorations more effective than } \\
\text { fine hybrid composites in class } \\
\text { II cavities? }\end{array}$ & $\begin{array}{l}\text { Both materials performed satisfactorily over the 4-year } \\
\text { observation period. }\end{array}$ & $1 b$ & 107 \\
\hline & $\begin{array}{l}\text { Does the use of bonding agents } \\
\text { improve the performance and } \\
\text { longevity of dental amalgam } \\
\text { restorations? }\end{array}$ & $\begin{array}{l}\text { There is no evidence to either claim or refute a difference in survival } \\
\text { between bonded and non-bonded amalgam restorations. }\end{array}$ & $2 a$ & 106 \\
\hline & $\begin{array}{l}\text { What are the survival rates of } \\
\text { fibre-reinforced resin-bonded } \\
\text { fixed partial dentures? }\end{array}$ & $\begin{array}{l}\text { The majority of the studies showed a survival rate of approx. } 72 \% \\
\text { after } 2-5 \text { years. This study highlights the need for good-quality } \\
\text { RCT. }\end{array}$ & $\mathrm{n} / \mathrm{a}$ & 75 \\
\hline & $\begin{array}{l}\text { Does listening to music reduce } \\
\text { anxiety in patients undergoing } \\
\text { root canal treatment? }\end{array}$ & $\begin{array}{l}\text { Music may reduce anxiety during invasive procedures in } \\
\text { adolescents and adults. }\end{array}$ & $1 b$ & 15 \\
\hline \multirow[t]{3}{*}{$\begin{array}{l}\text { Temporomandibular } \\
\text { disorders }\end{array}$} & $\begin{array}{l}\text { Is the nociceptive trigeminal } \\
\text { inhibition tension suppression } \\
\text { system device effective in the } \\
\text { treatment of temporomandibular } \\
\text { disorders and bruxism? }\end{array}$ & $\begin{array}{l}\text { The use of nociceptive trigeminal inhibition tension suppression } \\
\text { system splint may be justified in certain circumstances. }\end{array}$ & $1 a$ & 23 \\
\hline & $\begin{array}{l}\text { Is arthrocentesis and lavage an } \\
\text { effective treatment for } \\
\text { TMJ disorders? }\end{array}$ & $\begin{array}{l}\text { There is insufficient, consistent evidence to either support or } \\
\text { refute the use of arthrocentesis and lavage for treating patients with } \\
\text { TMJ disorders. }\end{array}$ & $2 a$ & 110 \\
\hline & $\begin{array}{l}\text { Are tricyclic antidepressants } \\
\text { effective in the treatment of TMJ } \\
\text { disorders? }\end{array}$ & $\begin{array}{l}\text { There is evidence, based on inconsistent or limited-quality data, } \\
\text { for the use of tricyclic antidepressants in the treatment of TMJ } \\
\text { disorders. }\end{array}$ & $2 b$ & 56 \\
\hline \multicolumn{5}{|c|}{$\begin{array}{l}\text { SDF, Silver diamine fluoride; ECC, early childhood caries; CHX, chlorhexidine; RCT, randomised controlled trial; HSV, herpes simplex virus; CHD, coronary heart } \\
\text { disease; TMJ, temporomandibular joint. }\end{array}$} \\
\hline \multicolumn{5}{|c|}{$\begin{array}{l}\text { 1. Lawrence A, Richards D. Questions answered in EBD volumes } 1 \text { and 2. Evid based Dent 2002; 3: 27-29. } \\
\text { 2. Richards D. Questions and answers in EBD volumes } 3 \text { and 4. Evid based Dent 2003; 4: 94-97. } \\
\text { 3. Richards D. Questions and answers and guidelines in EBD volume 5. Evid based Dent 2004; 5: 110-112. } \\
\text { 4. Richards D. Questions and answers and guidelines in EBD volume 6. Evid based Dent 2005; 6: 104-107. } \\
\text { 5. Richards D. Questions and answers and guidelines in EBD volume 7. Evid based Dent 2006; 7: 109-113. } \\
\text { 6. Richards D. Questions and answers and guidelines in EBD volume 8. Evid based Dent 2007; 8: 118-121. } \\
\text { 7. Richards D. Questions and answers and guidelines in EBD volume 9. Evid based Dent 2008; 9: 121-125. } \\
\text { 8. Richards D. Not all evidence is created equal — so what is good evidence? Evid based Dent 2003; 4: 17-18. }\end{array}$} \\
\hline
\end{tabular}

